\author{
Marek Pawlak \\ marek.pawlak@uj.edu.pl \\ Instytut Etnologii i Antropologii Kulturowej \\ Uniwersytet Jagielloński
}

\title{
ANTYCYPACJA, AFEKTYWNE EKONOMIE I TEMPORALNOŚĆ W (POST)KRYZYSOWEJ ISLANDII
}

\section{Anticipation, affective economies and temporality in (post)crisis Iceland}

Streszczenie. Neoliberalne przeobrażenia islandzkiej ekonomii politycznej i produkcja nowych subiektywności w latach 90 . XX wieku doprowadziły nie tylko do znaczących przemian społecznych i kulturowych w Islandii, ale także przygotowały podatny grunt na nadejście kryzysu ekonomicznego w 2008 roku. Jego doświadczenia i konsekwencje były oczywiście różne, aczkolwiek sam kryzys stał się także istotnym punktem na temporalnej mapie Islandii. Mimo że Islandia ponownie przeżywa dziś ekonomiczny boom, niepewna przyszłość wyłania się z teraźniejszości. Codzienne praktyki, zjawiska i znaczenia „ładują” atmosferę i stają się symptomami nadchodzącego kolejnego kryzysu. Celem tego artykułu jest zatem prześledzenie i sproblematyzowanie antycypacji, w ramach której wyłaniają się interesujące zależności pomiędzy przeszłymi zdarzeniami, teraźniejszymi doświadczeniami, a wyobrażeniami o nieznanej, aczkolwiek możliwej, przyszłości.

Słowa kluczowe: kryzys; antycypacja; temporalność; afekty; Islandia.

\begin{abstract}
Neoliberal reconfigurations of Icelandic political economy and the production of new subjectivities in the 1990s led not only to significant social and cultural changes in Iceland, but also prepared a fertile ground for crisis-to-come. The crisis itself was experienced differently, yet, it has also become a significant point of reference on Iceland's temporal map. Although Iceland is experiencing an economic boom today, an uncertain future is looming into the present. Everyday life matterings, practices and meanings "charge" the atmosphere and become symptoms of another crisis. The article aims to explore and
\end{abstract}


problematise affective anticipation, which unfolds the existing dependencies between past events, present experiences and future-oriented imaginaries.

Key words: crisis; anticipation; temporality; affects; Iceland.

\section{Wprowadzenie}

Droga z lotniska w Keflavíku do Reykjavíku zajmuje około godziny jazdy samochodem i biegnie wzdłuż oceanu, pól lawowych porośniętych mchem i szczytów górskich wyłaniających się na horyzoncie. To jednak nie malowniczy krajobraz przykuł moją uwagę w lipcu 2017 roku, kiedy po raz drugi przyleciałem do Islandii na kilkumiesięczne badania etnograficzne dotyczące migracji i kryzysu ekonomicznego, który miał miejsce w 2008 roku ${ }^{1}$. Niedaleko Keflavíku bowiem, w odległości kilku kilometrów od siebie, zauważyłem dwa lekko zabrudzone, stojące na poboczu - i z dala od zabudowań czy szlaków turystycznych - samochody typu SUV. Niemal natychmiast uruchomiły one moją etnograficzną wyobraźnię i wywołały afektywną mieszankę antycypacyjnej niepewności i ekscytacji. ,Zaczyna się...”, pomyślałem, sięgając jednocześnie etnograficzną pamięcią do różnych historii, o których słyszałem w terenie rok wcześniej.

Na pierwszy rzut oka samochód pozostawiony na poboczu nie wydaje się czymś szczególnym i wartym uwagi badawczej. W Islandii jednak nabiera on specyficznego znaczenia i powoduje afektywne rozpoznania. To bowiem samochody, porzucane na drogach w myśl zasady „łatwiej wziąć kredyt i kupić nowy, niż naprawiać stary”, były często przywoływane przez moich informatorów w celu wytłumaczenia i zobrazowania mi czasów przed-kryzysowych. Na początku XXI wieku Islandia przeżywała szybki wzrost gospodarczy, a luksusowe samochody stały się symbolem przynależności klasowej i wszechobecnej wówczas hiperkonsumpcji, która możliwa była za sprawą neoliberalnej polityki kredytowej i elastycznego systemu bankowego. Zatem, w przeddzień kryzysu ekonomicznego, na ulicach Reykjavíku jeździło wiele luksusowych marek typu Range Rover, Land Cruiser czy Hummer, które - już po doświadczeniach z 2008 roku - zaczęto ironicznie nazywać „Game Over”, „Grand

${ }^{1}$ Artykuł powstał w wyniku realizacji projektu badawczego „Polscy migranci w Islandii. Mobilne i niemobilne strategie reakcji na następstwa kryzysu ekonomicznego" (2014/15/D/HS6/04860) finansowanego ze środków Narodowego Centrum Nauki. 
Antycypacja, afektywne ekonomie i temporalność w (post)kryzysowej Islandii

Looser” i „Bummer”. Z bycia dystynkcją klasową, zwiastunem nieograniczonego wzrostu gospodarczego i wyobrażeniem na temat czekającej Islandię świetlanej przyszłość, stały się one afektywnym ucieleśnieniem niepewności i spekulacji na temat nadejścia kolejnego kryzysu. Co ciekawe, we współczesnym krajobrazie społecznym, kulturowym, ekonomicznym i politycznym Islandii wyłania się wiele tego rodzaju afektywnych „znaczności”, które uruchamiają lokalne wyobraźnie i „ładują” współczesną atmosferę (Stewart 2011). Przeszłość zdaje się ponownie wyłaniać w teraźniejszości, a jej doświadczanie i rozpoznawanie przyjmuje antycypacyjną formę narracji „Kryzys nadchodzi”, „Znowu to robią”, „To już tylko kwestia czasu kiedy to się stanie".

Antycypacja jest dziś częstym nastrojem w społeczeństwie islandzkim. Początkowo jednak, kiedy po raz pierwszy trafiłem na wyspę w 2016 roku, nie wydawała mi się ona aż tak istotnym polem eksploracji etnograficznych. Wręcz przeciwnie, zainteresowany byłem raczej doświadczeniami z przeszłości, afektywną pamięcią i strategiami radzenia sobie z sytuacją kryzysową, które starałem się problematyzować w oparciu o doświadczenia polskich migrantów w Islandii. Co więcej, na samym początku badań towarzyszyło mi raczej uczucie spóźnienia, będące rezultatem poszukiwania czegoś, co przecież już dawno minęło. Wrażenie bycia spóźnionym nieustannie potęgowane było przez Pawła, mojego kluczowego informatora w Reykjavíku, który za każdym razem, gdy przedstawiał mnie swoimi znajomym, mówił: „A to jest X, który jest antropologiem i przyjechał badać kryzys sprzed 10 lat". Tego rodzaju niewinne podkreślanie przeszłości kryzysu, któremu zawsze towarzyszył śmiech Pawła, wywoływało we mnie pewien dyskomfort bycia w ,złym” czasie. Żałowałem wręcz, że nie mogę obserwować kryzysu w antropologicznym „tu i teraz” i łapałem się na tym, że zazdroszczę wszystkim tym, którzy go doświadczyli. Przeszłość zaczęła prześladować mnie w teraźniejszości, czego rezultatem okazała się temporalna pułapka ,etnografii ratunkowej”, w której problematyzacje kryzysu ustąpiły miejsca naiwnie rozumianej „autentyczności” doświadczeń (por. Marcus 1986).

Niemniej, im częściej podczas rozmów wracałem do kontekstów przeszłości, tym bardziej musiałem wybiegać również w przyszłość. Moi informatorzy nieustannie przenosili się bowiem w swych opowieściach pomiędzy przeszłością, teraźniejszością a przyszłością, zrywając wręcz z temporalną linearnością. Kryzys okazał się bowiem nie tylko doświadczeniem z przeszłości, ale także kontekstem afektywnych spekulacji na 
temat nadchodzącej przyszłości. W konsekwencji, uruchomiło to moją krytyczną refleksyjność (Kazubowski-Houston 2018) i umożliwiło problematyzację tego, jak ludzie czują i wyobrażają sobie możliwe przyszłości oraz w jaki sposób sobie z nimi radzą. Mój teren poszerzył się jednak nie tylko temporalnie, ale również i społecznie. Początkowe różnice jakie obserwowałem pomiędzy polskimi migrantami a społeczeństwem islandzkim, sukcesywnie zaczęły ustępować podobieństwom w doświadczaniu teraźniejszości i narracji o przyszłości. Antycypacja kryzysu, mimo iż sama w sobie jest często zróżnicowana, zależna od rozmaitych praktyk i doświadczana $z$ różną intensywnością, wprowadza jednak także wartościowy poznawczo kontekst podobieństw związanych ze spekulacją na temat przyszłości. W konsekwencji, postanowiłem wyjść poza metodologiczny grupizm, w którym kategorie ,praktyczne” błędnie traktowane są jako ,analityczne” (zob. Brubaker, Cooper 2000). Z perspektywy antropologicznej bowiem, ,migranci” i „,społeczeństwo przyjmujące”, ,mniejszość” i ,większość”, czy w końcu ,polskości” i ,islandzkości” to fikcje (używane w codziennej praktyce), które często wytwarzają i ,naturalizują" hierarchie społeczne i kulturowe (por. Abu-Lughod 1991). Zatem, podążając za wyłaniającymi się w terenie problematyzacjami, w których globalne zależności i zróżnicowane lokalne światy zaczęły wzajemnie na siebie oddziaływać (Ong, Collier 2005), zacząłem eksplorować doświadczenia kryzysu, temporalności i praktyki antycypacyjne zarówno wśród polskich migrantów, jak i w społeczeństwie islandzkim. Pozwoliło mi to na skupienie uwagi etnograficznej nie tyle na tożsamościach, co raczej na przeżytych i przeżywanych doświadczeniach oraz codziennych praktykach społecznych.

W Islandii spędziłem łącznie dziewięć miesięcy prowadząc w latach 2016-2019 badania etnograficzne oparte na obserwacji uczestniczącej, uzupełnionej o nieformalne rozmowy i wywiady etnograficzne. Przebywałem głównie w Reykjavíku, przemieszczając się jednocześnie pomiędzy okolicznymi miastami, takimi jak Kópavogur, Hafnarfjörður, Hveragerði czy Keflavík. Ponadto, w 2016 roku, udałem się również na wschód wyspy do Egilsstaðir i Reyðarfjörður. Moi polscy informatorzy pochodzą z różnych części Polski, a większość z nich przyjechała do Islandii przed kryzysem ekonomicznym. Pracują też w różnych sektorach usług budowlanych i turystycznych (restauracje, hotele), jak również w firmach IT czy islandzkich instytucjach publicznych i państwowych (muzea, szkoły, urzędy). Chociaż moim głównym celem była współpra- 
Antycypacja, afektywne ekonomie i temporalność w (post)kryzysowej Islandii

ca terenowa z migrantami, którzy mieszkali na wyspie podczas kryzysu, postanowiłem również rozmawiać z osobami, które przyjechały do Islandii po recesji ekonomicznej. Pozwoliło mi to na prześledzenie różnic doświadczeń migracyjnych i sproblematyzowanie zależności pomiędzy kryzysem, afektywnością a temporalnością. Równie zróżnicowani byli moi islandzcy informatorzy, którzy pochodzili z różnych klas (niższa, średnia, wyższa średnia) i w różny sposób doświadczyli kryzysu i jego następstw. Są wśród nich pracownicy sektora usług budowlanych i turystycznych, emeryci, dziennikarze, urzędnicy miejscy i politycy różnych partii.

Co istotne, w trakcie badań blisko współpracowałem z moimi kluczowymi informatorami - Polakami i Islandczykami - z którymi mieszkałem lub spotykałem się przy rozmaitych, mniej lub bardziej formalnych, okazjach i dyskutowałem na temat wyłaniających się w terenie kontekstów badawczych. Uczestniczyłem także w różnego rodzaju wydarzeniach społecznych i politycznych (protesty, marsze, strajki) oraz towarzyszyłem moim kluczowym informatorom w praktykach codziennych (spacery, wycieczki, imprezy). Tego rodzaju etnografia - często określana jako deep hanging out - ma charakter otwarty, procesualny i zakłada podążanie za różnymi dyskursami, wyobrażeniami, praktykami, temporalnościami i afektami, które niespodziewanie pojawiają się w terenie. Pozwala to więc na refleksyjne i relacyjne rekonfigurowanie stawianych $\mathrm{w}$ terenie pytań i założeń oraz poddawanie ich procesowi nieustannej problematyzacji (Marcus 1995).

Zatem, podążając za wyłaniającymi się w terenie kontekstami, zaobserwowałem specyficzne zależności, w ramach których przeszłość i przyszłość zaczęły niemal współistnieć za sprawą temporalnych skojarzeń, a więc pewnego rodzaju sposobów wyjaśniania przeżywanego świata (por. Hastrup 2013: 78-82; Kleist, Jansen 2016: 8-10). W Islandii obserwowane i doświadczane w teraźniejszości praktyki, zjawiska, dyskursy i procesy naznaczone są przeszłymi znaczeniami, których ,powtarzalność” wytwarza wyobrażenia o możliwych przyszłościach. W konsekwencji, ponowne przeżywanie tego, co - jak podpowiada logika temporalności - powinno być przeszłe i minione wytwarza napięcie pomiędzy światem „,rzeczywistym” a „możliwym”, które przyjmuje formę afektywnych ekonomii (Ahmed 2004). Emocje ,wynurzają się” (ang. surfacing) wówczas jako element relacji społecznych, kulturowych, ekonomicznych i politycznych, łącząc to, co prywatne i codzienne, $\mathrm{z}$ tym, co publiczne i oficjalne (Ahmed 2004: 117; por. Richard, Rudnyckyj 2009). Tym samym, emocje, 
które przeżywane są indywidualnie jako „ucieleśnione myśli” (Rosaldo 1984), stają się doświadczeniem kolektywnym (Ahmed 2004), mającym wpływ na codzienność praktyk (Stewart 2007). Za sprawą afektywnych ekonomii, podziały na „umysł i ciało”, „prywatne i publiczne”, „sprawczość i strukturę" stają się bardziej procesualne, ukazując jednocześnie dynamikę relacji pomiędzy racjonalnością a doświadczeniem (Skoggard, Waterston 2015: 110-112; por. Lutz 2017; Pawlak 2018).

Celem tego artykułu jest prześledzenie afektywności kryzysu w Islandii i problematyzacja jednej z jego niezamierzonych konsekwencji - antycypacji - która może stanowić wartościowy poznawczo teren dociekań etnograficznych. Antycypacja jest bowiem stanem afektywnym, w ramach którego wyłaniają się interesujące zależności pomiędzy przeszłymi zdarzeniami, teraźniejszymi doświadczeniami, a wyobrażeniami o nieznanej, aczkolwiek możliwej, przyszłości. W kolejnych sekcjach artykułu, przedstawiam więc kontekst samego kryzysu - jego przyczyny i doświadczenia związane z neoliberalnym wytworzeniem nowych podmiotowości w społeczeństwie islandzkim. Szczegółowe prześledzenie tego „co stało się” w Islandii umożliwia bowiem lepsze zrozumienie istniejących afektywnych zależności pomiędzy przeszłością, teraźniejszością, a przyszłością. Następnie podejmuję próbę wyjaśnienia sposobów wytwarzania antycypacji, w których istotną rolę odgrywają temporalne skojarzenia i dostrojenia. Artykuł podsumowuję natomiast wskazaniem potencjału antropologii, w której perspektywa badawcza zorientowana na możliwe przyszłości może przyczynić się do lepszego zrozumienia naszego bycia w świecie glokalnych uwikłań.

\section{Kryzys: neoliberalna podmiotowość i afektywne ekonomie}

Kryzys ekonomiczny, który miał miejsce w Islandii w 2008 roku, pokazał istniejące powiązania pomiędzy globalnymi siłami, lokalnymi wyobrażeniami i umiejscowionymi praktykami. Islandia nie była już odizolowaną wyspą, leżącą gdzieś na północnym Atlantyku (por. Hastrup 1998). Wręcz przeciwnie, przed i w trakcie kryzysu, była już silnie osadzona w globalnych reżimach zależności ekonomicznych i politycznych (Durrenberger, Pálsson 2015). Było to rezultatem neoliberalnej rekonfiguracji islandzkiej ekonomii politycznej i afektywnego produkowania nowych podmiotowości (por. Richard, Rudnyckyj 2009), co doprowadziło nie tylko do znaczą- 
Antycypacja, afektywne ekonomie i temporalność w (post)kryzysowej Islandii

cych przeobrażeń społecznych w Islandii, ale także przygotowało podatny grunt na nadejście samego kryzysu.

Prywatyzacja przemysłu rybnego w latach 80 . XX wieku i wprowadzenie kwot połowowych to tylko początek neoliberalnych przeobrażeń w Islandii (Pálsson 1993, 1996). Ideologia neoliberalna wprowadzona została bowiem nie tylko jako projekt polityczny i ekonomiczny, ale także społeczny, któremu towarzyszyły liczne racjonalizacje (i naturalizacje) w oparciu o dyskursy modernizacyjne państwa (Pálsson 1993). Dominowała więc wówczas narracja „totalnej efektywności” i potrzeba ,zarządzania" islandzkim społeczeństwem i naturą (Pálsson 1996). W momencie, gdy tylko ryby „ewoluowały” z bycia „dobrem wspólnym” do bycia „towarem”, na wyspie pojawili się „,nowi bankierzy” z neoliberalną agendą finansową i nowymi praktykami bankowymi (Mixa 2009, 2015). Lata 90. XX wieku, to zatem czas podejmowania dużego ryzyka inwestycyjnego, które miało przynieść Islandii świetlaną przyszłość. Islandzkie banki, posiadające niewielki kapitał założycielski i będące wcześniej zależnymi od państwa, szybko zostały sprywatyzowane i trafiły na globalny rynek spekulacji (zob. Alibar, Zoega 2011). Neoliberalne przeobrażenia islandzkiego systemu finansowego rzeczywiście doprowadziły do gwałtownego wzrostu gospodarczego, jednak miał on charakter tymczasowy i krótkowzroczny, a jego konsekwencje miały dopiero nadejść (zob. Bergmann 2014; Durrenberger, Pálsson 2015).

Na początku XXI wieku szybki rozwój gospodarczy Islandii i towarzyszące mu praktyki społeczne określone zostały jako „szaleńcze millenium” (Mixa 2009, 2015). Były to czasy útrásarvíkingur - „wikinga biznesu" - a więc nowego islandzkiego finansisty, którego głównym celem był podbój świata globalnej ekonomii. W języku islandzkim, słowo útrás oznacza „ekspansję” i w czasach gospodarczego boomu pomiędzy 2003 a 2008 rokiem było idiomem kulturowym służącym do wyjaśnienia zachodzących zmian w krajobrazie społecznym, ekonomicznym i politycznym wyspy. „Wikingowie biznesu” zyskali wręcz status celebrytów, a islandzkie media rozpisywały się na temat ich kolejnych globalnych podbojów - kupna hoteli, apartamentów, jachtów, klubów piłkarskich czy też imprezach, na których widziano ich w towarzystwie międzynarodowych gwiazd sportu (Loftsdóttir 2015: 10). Ich sława sprawiła, że znaczna część społeczeństwa islandzkiego uznała „wikingów biznesu” za pionierów odkrywających przyszłość i poszła w ich ślady, oddając się hiperkonsumpcji. 
W trakcie moich badań, przywoływanie kontekstu „szaleńczego milenium" wywoływało u moich informatorów podniosły nastrój, połączony z afektywną mieszanką dumy, gniewu, niechęci czy nawet postawy (samo)krytyki. Jak zauważył na przykład Sigmar, dziennikarz pracujący $\mathrm{w}$ jednej z islandzkich stacji radiowych, $\mathrm{z}$ którym spotkałem się w jednym z pubów w Reykjavíku:

Świętowaliśmy wtedy nasz sukces i wyjątkowość islandzkiego biznesu. Ludzie byli dumni z tego, że nasze małe społeczeństwo odniosło tak wielki sukces. Islandczycy kupowali wtedy zagraniczne nieruchomości i firmy. Na rok przed kryzysem, nikt niczego się nie spodziewał. Mój ojciec kupił mi wtedy samochód, a jeszcze nie miałem prawa jazdy, bo byłem za młody. W mojej szkole przed 2007 rokiem, każdy miał samochód i wszyscy mieszkali w wielkich domach.

Z Sigmarem spotkaliśmy się kilka razy przy różnych okazjach, ale tego wieczoru w pubie rozmawialiśmy o doświadczeniach kryzysu i jego wspomnieniach dotyczących czasów przedkryzysowych. Sigmar mówił dużo o dumie i celebracji ekonomicznego boomu, co podnosiło status kraju na arenie międzynarodowej, jako państwa godnego naśladowania. Duma była szczególnie istotna w momencie, gdy media informowały o ,wikingach biznesu", kupujących nieruchomości w Danii, co według Sigmara świadczyć miało o odwróceniu kolonialnych zależności. Interesujące jednak było również to, że w kontekście przypominania sobie przeszłości, Sigmar w pewnym momencie powiedział: „Pamiętam ten konsumpcjonizm wtedy. Ale wiesz, dzisiaj znowu go widzimy. Wszyscy teraz szaleją, bo otwierają nowy H\&M w tym miesiącu. To jest to samo uczucie, które pamiętam z przeszłości”. Tego rodzaju skojarzenia przeszłości z teraźniejszością były częstym elementem prowadzonych przeze mnie rozmów i obserwacji. Współczesna sytuacja społeczna, ekonomiczna i polityczna w Islandii często służyła więc jako kontekst porównań, powiązań, a nawet i kontynuacji pomiędzy przeszłymi a teraźniejszymi doświadczeniami, które automatycznie projektowane były na przyszłość.

Podobnie było w przypadku wielu polskich migrantów, dla których pewne aspekty „szaleńczego milenium” ponownie wyłaniają się $\mathrm{w}$ islandzkim krajobrazie. Różnica jednak polega na tym, że islandzkie praktyki konsumpcyjne z czasów „szaleńczego milenium” były przez nich trudne do zrozumienia. Robert, który zaczynał na wyspie jako pracownik 
Antycypacja, afektywne ekonomie i temporalność w (post)kryzysowej Islandii

budowlany, a dziś jest właścicielem firmy turystycznej, powiedział podczas naszego spotkania:

Znajomy Islandczyk ma salon samochodowy i kiedyś go pytałem, jak to było z tym kryzysem. A on mówi, że były sytuacje, że o 10:00 otwierał salon, wpadał chłopak, 19 lat, i za chwilę wyjeżdżał dwuletnim BMW. Rzucał mu złotą kartę kredytową na stół i tyle. Zapytałem go, no ale jak to było możliwe, a on mi na to, że to wszystko było proste, bo każdy kto zaczynał pracę, szedł do banku i od razu z miejsca mógł poprosić o wyrobienie karty kredytowej. No i w banku mówili ok, to limit na koncie to milion koron. No i wiesz, nagle dostawałeś milion koron na karcie, a jak przychodził koniec miesiąca i trzeba było kartę kredytową spłacić, to wyobraź sobie, że bank nie wymagał tej spłaty, a następnego miesiąca miałeś kolejny milion do wykorzystania. I tak to wszystko wyglądało. Wszyscy wtedy chodzili w garniturach, nawet łebki, co po 16 lat mieli. No i wiesz, ja w lokalu rzucałem niebieską debetówką, a oni wszyscy złotymi kartami VISA.

Dla Roberta „szaleńcze milenium” było czasami absurdu, będącego rezultatem deregulacji systemu kredytowego. Podobnego zdania była Kasia, która w Islandii prowadzi jeden $\mathrm{z}$ wielu portali internetowych dla polskich migrantów: „Tutaj wszyscy wtedy dostawali karty kredytowe i nikt nie zastanawiał się, że te pieniądze nie istnieją. Po prostu szli i kupowali, co chcą - mieszkania, samochody, wszystko co im się zamarzyło, a reszta szła do śmieci. Nikt się nad tym nie zastanawiał".

„Szaleńcze milenium” było jednak również krytykowane przez samych Islandczyków. Tak było w przypadku Hrafna, z zawodu elektryka, którego spotkałem w Keflavíku. W latach 90. wyjechał do Kanady, z której powrócił w momencie, gdy „szaleńcze milenium” osiągało swój punkt kulminacyjny. Podczas naszej rozmowy o doświadczeniach tamtego okresu, Hrafn stwierdził:

Wszyscy byli pretensjonalni, rozmawiali tylko o swoich nowych jeepach. Pamiętam, że nie miałem wtedy pojęcia, skąd na to wszystko były pieniądze. Bo co produkuje Islandia? Jak te pieniądze powstawały? Pamiętam, że pytałem o to ludzi, ale odpowiedzi zawsze były mgliste, myślę że nikt tego wtedy nie rozumiał. [...] Miałem nadzieję, że będzie kryzys, bo nie podobała mi się atmosfera w 2007 roku. A jak przyszedł kryzys to straciłem wtedy pracę, ale nie przejmowałem się - dorabiałem naprawiając pralki i suszarki. Ludzie zaczęli naprawiać sprzęty, 
inaczej niż w 2007 kiedy po prostu kupowali nowe. Naprawianie nie miało wtedy sensu, po prostu wyrzucano sprzęt do śmieci i kupowano nowy. To było marnotrawstwo, nienawidziłem tego okresu. [...] Jak tu wróciłem w 2006 roku, to myślałem, że wracam do socjalistycznej Islandii, gdzie ludzie troszczą się o siebie, a nie konkurują. Ale okazało się, że wróciłem do menedżerskiej Ameryki. To było okropne, taki konsumpcjonizm na sterydach. [...] Więc jak przyszedł kryzys, to cieszyłem się.

„Szaleńcze millenium” było konsekwencją neoliberalnej rekonfiguracji państwa, ekonomii i społeczeństwa. W Islandii ideologia ta trafiła na niezwykle podatny grunt i została silnie powiązana z dyskursem nacjonalistycznym i postkolonialnymi uwikłaniami (Loftsdóttir 2012, 2015, 2016). W dyskursie politycznym zaczęła wówczas dominować narracja o specyficznym ,,islandzkim charakterze” czy wręcz predestynacji Islandczyków do globalnej ekspansji i rozwoju. Korzeni sukcesu i uzasadnienia dla szybkiego wzrostu gospodarczego szukano więc w przeszłości i ,dziedzictwie indywidualizmu, silnych przywódców, solidarności, śmiałości, zaufania, honoru i umiejętności poetyckich" (Jóhannesson 2015: 20).

W czasach ekonomicznego boomu, gloryfikowana przeszłość służyła jednak nie tylko wyjaśnianiu i uzasadnianiu działań w teraźniejszości, ale również projektowaniu najbliższej przyszłości. Islandczycy, niczym wikingowie, ponownie więc byli pionierami, ale tym razem podbijając nowy neoliberalny świat (zob. Loftsdóttir 2015: 9-12). Tego rodzaju dyskurs nacjonalistyczny ujawnił także istniejący w Islandii kontekst postkolonialnych zależności, uwikłań i kompleksów (Loftsdóttir 2016). „Szaleńcze milenium" było postrzegane jako przeobrażenie historycznych powiązań z Danią i rekonfiguracja wcześniejszych relacji władzy. Za sprawą szybkiego wzrostu gospodarczego, Islandczycy pozbyli się kulturowego niepokoju, który wyrastał z przekonania, że arena międzynarodowa ma błędne wyobrażenia o Islandii i „nie widzi ich wyjątkowości”, nowoczesności i przynależności do świat zachodniego (Loftsdóttir 2015: 11; zob. także Loftsdóttir 2010, 2012, 2016, 2018).

Neoliberalizm odegrał niezwykle znaczącą rolę w wytwarzaniu nowych podmiotowości w Islandii, czego konsekwencją było przyjęcie „wolnorynkowej mantry” i wiara społeczeństwa w jej „harmonię i stabilność” (Mixa 2015: 43). „Szaleńcze milenium” było radykalnie nowym doświadczeniem społecznym, kulturowym, ekonomicznym i politycznym, które stało w sprzeczności z wcześniejszym przekonaniem o islandzkiej 
Antycypacja, afektywne ekonomie i temporalność w (post)kryzysowej Islandii

wspólnotowości i równości (Loftsdóttir 2015: 10; por. Durrenberger, Pálsson 1989; Pálsson, Durrenberger 1996). Wytworzyło ono nowe podmiotowości, dla których dystynkcje klasowe stały się istotnym elementem praktyk tożsamościowych. Neoliberalny kapitalizm doprowadził więc do powstania zależności, w ramach których „dyskursy emocjonalne i ekonomiczne oraz praktyki kształtują siebie nawzajem" (Illouz 2010: 10). W rezultacie tego, wszelkie ,zachowania ekonomiczne" stały się afektywne (Illouz 2010: 11; por. Richard, Rudnyckyj 2009). Mówiąc inaczej, praktyki hiperkonsumpcji podczas ,szaleńczego milenium” afektywnie zaczęły oddziaływać na relacje społeczne w Islandii, a towarzyszące im indywidualne emocje ,wynurzyły się" w dyskursie publicznym, tworząc jednocześnie afektywne ekonomie (Rudnyckyj 2009: 58-59; por. Ahmed 2004; Richard).

Lepsza przyszłość, którą obiecywano w czasach ,szaleńczego milenium" nigdy jednak nie przyszła. Wręcz przeciwnie, szybki wzrost gospodarczy i hiperkonsumpcja zostały niespodziewanie zahamowane przez globalny kryzys finansowy w 2008 roku, a Islandia trafiła na międzynarodowe okładki gazet jako państwo ,zepsute” i ,zrujnowane” (Pálsson, Durrenberger 2015: XV-XVIII). Nastały wówczas czasy niepewności, społecznej frustracji i gniewu. Rząd został rozwiązany, a nowi politycy powołani do zarządzania kryzysem, musieli mierzyć się z rewolucyjnym ruchem ,garnków i patelni”, protestującym wówczas na ulicach Reykjavíku (Bernburg 2015). W skali makro kryzys był oczywiście poważny. Islandzka korona radykalnie straciła na wartości, a inflacja zaczęła mieć poważne konsekwencje dla domowych budżetów. Państwo zmuszone było do interweniowania w system bankowy, a ,wikingów biznesu” i ich praktyki niemal natychmiast okrzyknięto główną przyczyną kryzysu (Bergmann 2014; Boyes 2009; Durrenberger, Pálsson 2015).

Same doświadczenia kryzysu były jednak bardzo zróżnicowane i w znacznej mierze zależne od przynależności klasowej, praktyk konsumpcyjnych czy też indywidualnych zobowiązań kredytowych zaciągniętych podczas „szaleńczego milenium”. Z pewnością jednak kryzys stał się niezwykle znaczącym punktem odniesienia, pewnego rodzaju schematem odczytywania tego, co dzieje się wokół i dominującym tematem rozmaitych dyskusji. Był to jeden z tych momentów, o których łatwo się nie zapomina. Większość osób, które spotkałem w terenie, nie miała więc problemu z przywołaniem sytuacji, kiedy po raz pierwszy usłyszały o kryzysie. Dla Haddy na przykład, moment kryzysu był sporym zasko- 
czeniem. Kiedy spotkaliśmy się w Reykjavíku, żeby porozmawiać o jej doświadczeniach, swoją narrację zaczęła właśnie od tego momentu:

Uczyłam wtedy w szkole i byłam właśnie z uczniami, kiedy dostałam smsa o treści „włącz telewizor”. I wszyscy zaczęliśmy oglądać, co się dzieje, a dzieci wciąż mnie pytały „Co to znaczy, Hadda? Co to znaczy?” A ja nie wiedziałam i tylko myślałam sobie „Cholera, jak bardzo jest źle?”. Pamiętasz to przemówienie Haarde? To, które zakończył „Niech Bóg błogosławi Islandię”? To było dla nas wszystkich zaskoczenie, to było bezprecedensowe, więc wszyscy wiedzieliśmy, że jest naprawdę źle. I wiesz, to nie było tak, że wiedzieliśmy, że kryzys będzie, nie wiedzieliśmy, że nadchodzi.

Hadda nawiązuje tu do przemówienia premiera Islandii, Geira Haarde, który 6 października 2008 roku, opisując sytuację kraju, użył zwrotu nigdy wcześniej nie słyszanego z ust polityka. Bezpośrednie nawiązanie do Boga, dla większości Islandczyków „oznaczało całkowitą stratę, porzucenie i głębokie poczucie, że państwo straciło kontakt z rzeczywistością, nie jest zarządzane i funkcjonuje poza racjonalnością" (Pálsson, Durrenberger 2015: XIX). Przyszłość w Islandii stała się niepewna i rysowana w raczej ciemnych barwach. W konsekwencji, Hadda musiała migrować w poszukiwaniu pracy, dzięki której byłaby w stanie spłacać raty kredytu mieszkaniowego. W jej ślady poszło również wielu innych Islandczyków, którzy zaczęli wyjeżdżać ,za pracą” do Danii czy Norwegii, ironizując przy tym, że „teraz to jesteśmy jak Polacy” (Guðjónsdóttir, Loftsdóttir 2016: 11-13).

W podobnej sytuacji byli też polscy migranci. Kryzys dotknął w szczególności pracowników budowlanych, którzy zostali niejako zmuszeni do wyjazdu z Islandii, ponieważ z dnia na dzień wstrzymane zostały wszystkie budowy, wygasły różnego rodzaju zlecenia, kontrakty i umowy (zob. Skaptadóttir 2015). Niemniej wielu migrantów postanowiło jednak zostać na wyspie i spróbować odnaleźć się w nowej, pokryzysowej rzeczywistości (zob. Wojtyńska, Skaptadóttir, Ólafs 2011). Z pomocą przyszło im państwo islandzkie, które zapewniało miesięczne wypłaty zasiłku dla bezrobotnych. Aczkolwiek większość osób, które spotkałem w terenie bardzo szybko odnalazło się w nowej sytuacji i nie miało poważniejszych problemów ze znalezieniem innej pracy. Tak było w przypadku Basi, która do Islandii przyjechała w 2008 roku, na kilka miesięcy przed kryzysem: 
Antycypacja, afektywne ekonomie i temporalność w (post)kryzysowej Islandii

Nienawidzę tej historii, bo od maja 2008 roku, przez trzy miesiące pracowałam na lotnisku w Keflavíku, ale potem nastąpił cały szereg wydarzeń i w dziwnych okolicznościach zostałam zwolniona. Nikt mi tego do końca nie wyjaśnił, ale pogłoski o nadchodzącym kryzysie przebrzmiewały już gdzieś tam w sierpniu i oni wpadli w taki szał trochę. No ale później dostałam pracę w hotelu w Reykjavíku i pamiętam, mój pierwszy tydzień w pracy, przychodzę i wszyscy czytają gazety, że korona idzie w dół i po prostu wszyscy mieli śmierć w oczach. No ale większość z nas mieszkała w wynajmowanych mieszkaniach, nie mieliśmy żadnych kredytów pobranych, a jeżeli już, to one były w Polsce. Największym problemem było tylko to, że poblokowali wysyłanie pieniędzy za granicę.

Basia, tak jak wiele innych osób, straciła pracę, ale szybko zamieniła ją na nową. Dla migrantów, którzy nie zdążyli się jeszcze „osadzić” w islandzkich warunkach, kryzys nie okazał się poważnym problemem. W terenie często spotykałem się więc z pewnego rodzaju (neoliberalną) elastycznością, która - wpisana niejako w praktyki migracyjne - okazywała się skuteczną strategią radzenia sobie z konsekwencjami kryzysu. Na przykład, praca $\mathrm{w}$ restauracji czy hotelu zamieniana była na pracę $\mathrm{w}$ przedszkolu, a zatrudnienie przy budowach na pracę jako pomoc mechanika.

Dla Marcina natomiast, który w Islandii mieszka od 2006 roku, kryzys nie odegrał żadnej znaczącej roli. Kiedy spotkaliśmy się po raz pierwszy w 2016 roku i rozmawialiśmy o jego doświadczeniach z przeszłości, powiedział:

Dla mnie osobiście ten kryzys to był taki trochę szum w tle, bo ja byłem zaoferowany tym, co robię. No ceny poszły w górę, ale my byliśmy na tyle krótko przed kryzysem, że nam się ta rzeczywistość wydawała, że po prostu się zmienia z dnia na dzień. Przez pierwszy rok dorabiałem też jako kierowca w pizzerii, więc jakieś dodatkowe pieniądze miałem. No a jak ktoś ci podniósł czynsz, no to po prostu płacisz więcej. Więc mniej więcej tego kalibru to było dla nas wydarzenie - coś się stało, ale my byliśmy jeszcze nieokrzepli w tej rzeczywistości islandzkiej. Kryzys był, ale te ceny nie uderzyły w nas aż tak bardzo, bo też nie mieliśmy tej konsumpcji, wiesz, na takim poziomie.

Kryzys, doświadczany jako „szum w tle”, o którym wspomina Marcin, nie był dla mnie dużym zaskoczeniem. W rzeczywistości, bardzo często spotykałem się $\mathrm{w}$ terenie $\mathrm{z}$ pewnego rodzaju obojętnością wobec kryzysu, która towarzyszyła zarówno migrantom, jak i Islandczykom. 
Najczęściej przybierała ona formę narracji: „Kryzys? Jaki kryzys? W Polsce to mamy kryzys” lub też „Kryzys był, ale mnie nie dotyczył. Byłem i jestem biedny”. Interesujące dla mnie okazało się natomiast to, że „obojętność indywidualnych doświadczeń z przeszłości, zaczęła komplikować się w momencie, gdy dyskusja schodziła na teraźniejszość. Kryzys bowiem - mimo że pociągał za sobą różne konsekwencje i doświadczany był z różną intensywnością - stał się znaczącym punktem na temporalnej mapie Islandii. Niemożliwa więc była rozmowa na temat przeszłości, bez nawiązywania do tego, co obecnie dzieje się na wyspie, jak również spekulowania na temat tego, co za chwile może się wydarzyć. W moim terenie, linearna logika temporalności przestała obowiązywać, a przeszłość, teraźniejszość i przyszłość stały się niemal równoczesne.

\section{Antycypacja, temporalne skojarzenia i dostrojenia}

We współczesnej Islandii, niedawna przeszłość wyłania się w teraźniejszości i wytwarza spekulacje na temat najbliższej przyszłości. Islandia ponownie bowiem przeżywa ekonomiczny boom, a Reykjavík jest dziś jednym wielkim placem budowy. Rozsiane po całym mieście żurawie budowlane afektywnie „ładują” atmosferę (por. Stewart 2011) i przypominają o konsekwencjach „szaleńczego milenium”. Dla Natalii, która do Islandii przyjechała w latach 90. XX wieku, obecny krajobraz miasta uruchamia znane jej doświadczenia:

Sytuacja jest podobna, no przecież tylko spójrz na te podobieństwa wszędzie. Nie wiemy czy kryzys będzie czy nie, ale warunki są te same. No zobacz, na przykład te żurawie budowlane wszędzie... mówi się, że to symbol rozwoju ekonomicznego, ale przecież one są wszędzie...

W Islandii krajobraz żurawi budowlanych wprowadza pewien element niepewności i spekulacji. Nie są one bowiem postrzegane tylko jako zwykłe dźwigi, ale również jako „islandzki las”, który wyrasta na bezdrzewnej przecież wyspie, czy też „ptaki narodowe”, których sezonowa „migracja” zwiastuje nadejście kolejnego kryzysu. W konsekwencji, budowane nowe hotele, luksusowe apartamenty i centra handlowe stają się symptomami i uruchamiają stan niepewności, przypominając jednocześnie o czasach „szaleńczego milenium”. Teraźniejszość staje się znacząca i wprowadza kontekst antycypowania kolejnego kryzysu w niedalekiej przyszłości. 
Antycypacja, afektywne ekonomie i temporalność w (post)kryzysowej Islandii

Kiedy w jednej z kawiarni w centrum Reykjavíku poznałem Erica Amerykanina z islandzkim obywatelstwem, mieszkającego w Islandii od 1999 roku - to właśnie tego rodzaju antycypacja kryzysu zdominowała naszą rozmowę. W pewnym momencie Eric zaczął wręcz wyliczać odczuwalne symptomy, które jego zdaniem świadczą o zbliżającym się kryzysie:

Wiele wskazuje na kryzys. Ten ekonomiczny boom, który jest teraz, to zaczął się już mniej więcej w 2011 roku. Wtedy znowu zaczęły pojawiać się żurawie, których nie było tuż po kryzysie. Dziś znowu jest ich pełno i zaczęły się przemieszczać. Jest też więcej kokainy w mieście, tak jak było przed kryzysem, a jeśli to nie jest oznaka dobrych czasów to nie wiem co innego może być. Znowu jest więcej Range Roverów na ulicach, jest też problem z rynkiem mieszkaniowym.

Ożywienie islandzkiej gospodarki i towarzyszące mu symptomy, przypominają o niedawnej przeszłości ,szaleńczego milenium” i jego kryzysowych konsekwencjach. Ich doświadczanie w teraźniejszości odczytywane jest natomiast nie tyle jako przypomnienie o tym, „co się wydarzyło”, ale raczej jako wyobrażanie sobie tego, „co się wydarzy”. Obecna sytuacja społeczna, ekonomiczna i polityczna w Islandii uruchamia więc afektywne doświadczenia z przeszłości, które niemal natychmiast projektowane są na przyszłość, wywołując jednocześnie antycypacyjne nastroje. Podczas jednej z naszych rozmów Basia jednoznacznie stwierdziła, że:

Czekamy teraz na następny kryzys, bo wszyscy wiedzą, jak to było wtedy. Wystarczy choćby spojrzeć na to, co dzieje się z kursami walut, wtedy też było szaleństwo. Życie było tu wtedy bardzo komfortowe, było pełno ofert pracy, wszystko było w budowie, każdy miał mieszkanie. Ludzie teraz widzą, że to dokładnie ta sama sytuacja, ten sam scenariusz co przed 2008 rokiem. Wtedy było dokładnie tak samo, każdego było stać na samochód, mieszkanie, banki dawały na wszystko kredyt. Więc wiesz, my już to przerabialiśmy.

„Szaleńcze milenium” i kryzys ekonomiczny silnie odbiły się na wyobraźni społecznej Islandii, stając się przy tym afektywnym sposobem doświadczania temporalności. Żurawie budowlane, luksusowe samochody, praktyki konsumpcyjne czy nawet coś tak zdawałoby się banalnego jak wakacje w „egzotycznych” krajach, nie są więc zwyktymi aspektami i praktykami w islandzkiej codzienności. Wprowadzają one bowiem 
kontekst antycypacji i możliwych przyszłości, przesuwając tym samym uwagę badawczą z tego, co „było” na to, „co będzie”. Pojawia się więc interesujący kontekst afektywnych zależności pomiędzy temporalnymi skojarzeniami, antycypacją i sprawczymi w swej formie dostrojeniami (por. Hirsch, Stewart 2005; Kleist, Jansen 2016: 8-10; Knight, Stewart 2016; Stewart 2011).

Dynamiczny charakter relacji pomiędzy przeszłością, teraźniejszością a przyszłością jest nieodłącznym doświadczeniem codzienności (Munn 1992; Hirsch, Stewart 2005). Forma praktyk społecznych i znaczeń kulturowych uwarunkowana jest bowiem nie tylko przeszłymi przeżyciami, ale również wytwarzanymi oczekiwaniami wobec nadchodzącej, możliwej przyszłości. Oczywiście, zarówno przeszłość, jak i przyszłość, są selektywne, polityczne, zazwyczaj wytwarzane (wyobrażane) ideologicznie, co służyć ma osiąganiu partykularnych celów. W konsekwencji, są one wzajemnie uwarunkowane, relacyjne i oddziałują na siebie za sprawą komunikowanych społecznie znaczeń, praktyk, procesów i zjawisk (por. Hirsch, Stewart 2005: 269).

Mimo że przeszłość i przyszłość nie są nam bezpośrednio dostępne, wyobrażenia o nich wytwarzane są w doświadczeniach teraźniejszości. Przeszłość (polityka pamięci, wspomnienia) oraz przyszłość (oczekiwania, aspiracje, spekulacje) są więc rezultatem temporalnych skojarzeń, które uobecniają i aktualizują różne wersje zarówno tego, co „było”, jak i tego, co „będzie” w odniesieniu do „zdarzeń, politycznych potrzeb, dostępnych form kulturowych i dyspozycji emocjonalnych" (Hirsch, Stewart 2005: 262; por. Knight, Stewart 2016: 6-9). Temporalne skojarzenia przypominają więc w swych znaczeniach „,historyczność”, która w przeciwieństwie do „historii”, konstruowana jest w oparciu o indywidualne doświadczenia i wyłania się jako rezultat złożonych relacji społecznych i politycznych (Hirsch, Stewart 2005: 261-263; por. Kleist, Jansen 2016). W temporalnych skojarzeniach nie chodzi więc o żaden „obiektywizm” tego, co dzieje się wokół, a raczej o ucieleśnienie aktualnych relacji, praktyk i procesów, które nabierają afektywnego wymiaru. Tym samym, temporalne skojarzenia są performowane w nieustannym ruchu pomiędzy doświadczeniami przeszłości, a wyobrażeniami o przyszłości, co wskazuje na relacyjność wiedzy i kontekstualność znaczeń doświadczanych w teraźniejszości.

W Islandii temporalne skojarzenia uruchamiają afektywną antycypację, która „przenika sposoby myślenia, odczuwania i strategie rozwiązy- 
Antycypacja, afektywne ekonomie i temporalność w (post)kryzysowej Islandii

wania problemów" (Adams, Murphy, Clarke 2009: 248). Antycypacja jest kontekstowa i wielowymiarowa, i ujawnia uwikłania lokalnych doświadczeń w globalnych zależnościach, wskazując jednocześnie na aktywne pozycjonowanie się $\mathrm{w}$ czasie, pomiędzy przyszłością, teraźniejszością a przeszłością (Adams i in. 2009: 247). W konsekwencji, antycypowanie tego, co (być) może się wydarzy ma „efekt falujący”, ponieważ emocje z tym związane komunikowane są społecznie za pomocą ,skojarzeń pomiędzy znakami, figurami i przedmiotami" (Ahmed 2004: 120). Tego rodzaju afektywna ekonomia sprawia, że antycypacja staje się „reżimem bycia w czasie" (Adams i in. 2009: 247), w ramach którego wyobrażana przyszłość jest możliwa, ale oczywiście jeszcze nie przesądzona. Antycypacja łączy więc różnego rodzaju sposoby myślenia o świecie, formy jego doświadczania oraz działania społeczne z elementami niewiedzy, ponieważ o przyszłości możemy jedynie spekulować (zob. Pink, Salazar 2017; por. Appadurai 2013). Niemniej nie oznacza to, że przyszłość - nawet jeśli jest ona „ewentualna”, często „przypadkowa” i ,zdarzeniowa” - nie ma wpływu na teraźniejszość, praktyki codzienności, wiedzę kulturową i relacje społeczne (zob. Pink, Salazar 2017: 16). Już przecież samo jej antycypowanie posiada znamiona ,wytwarzania jutra” (tomorrowing), w ramach którego istniejące wyobrażenia lub spekulacje na temat przyszłych „możliwości” przekuwane są w teraźniejsze praktyki (por. Salazar 2017). Ma to zazwyczaj charakter eksperymentalny, który często bywa też nieprzewidywalny w swych skutkach. Niemniej ,jutro" nieustannie jest wytwarzane w teraźniejszości, czy to w kontekście rozwoju technologicznego i jego zastosowań społecznych (Adams i in. 2009), zarządzania i planowania (zob. Abram, Weszkalnys 2013) czy też ekonomii, która sama w sobie jest spekulatywna i w dużej części opiera się na różnego rodzaju prognozach (Holmes, Marcus 2006).

Perspektywa skierowana na przyszłość, jej wyobrażanie i antycypowanie, pozwala więc na ćwiczenie różnych możliwości w czasie teraźniejszym, które często nie są jedynie ,praktycznymi zastosowaniami” - jak to często bywa w kontekście nowych technologii - ale także informują nas o istniejących obawach i troskach związanych z „odległymi, możliwymi scenariuszami przyszłości” (Hastrup 2013: 22). Jest to szczególnie widoczne w badaniach i rozważaniach dotyczących zmian klimatycznych i katastrof ekologicznych, w ramach których antycypacja przyszłości i prognozowanie tego, co będzie, stanowi istotny element strategii reagowania (Connor, Marshall 2015; Hastrup, Skrydstrup 2013). W pewnym 
więc sensie, ,przyszłość zamieszkuje teraźniejszość, nawet jeśli jeszcze nie nadeszła” (Fortun 2012: 450). Jej „znaczenia”, ,struktury” i ,powinności" - jak również obawy, niepewności i nadzieje - wytwarzane są w teraźniejszości (Fortun 2012: 450) i doświadczane za pośrednictwem temporalnych skojarzeń.

Przyszłość jest zatem „faktem kulturowym” (Appadurai 2013), a jej antycypowanie pozwala prześledzić istniejące konteksty wyobrażeń, praktyk i relacji społecznych, jak również strategie racjonalizacji doświadczeń i sposoby myślenia o świecie. W konsekwencji antycypacja ma wartość poznawczą dla antropologii, ponieważ wskazuje na istniejące zależności pomiędzy przeszłymi zdarzeniami a przyszłymi możliwościami, które rozgrywane są jako aktualne w dynamice teraźniejszości (Salazar 2017: 155). Z jednej więc strony, perspektywa badawcza zwrócona W stronę antycypacji przyszłości we współczesnym świecie, przypomina nam o tym, że w rzeczywistości nigdy nie jesteśmy w stanie przewidzieć, co się wydarzy; z drugiej jednak, uzmysławia nam także istniejącą tendencję do społecznego wyobrażania sobie świata zarówno w oparciu o to, co już się zdarzyło, jak i o to, co zakładamy, że dopiero się zdarzy (por. Pink i Salazar 2017: 17).

Antycypacja „ładuje” tym samym atmosferę teraźniejszości (zob. Stewart 2011) i „określa możliwości działań” (Adams i in. 2009: 249) będące reakcją zarówno na przeszłość, jak i przyszłość (Hastrup 2005: 8). W konsekwencji wywołuje ona dostrojenia, które są sprawcze w swej formie (Stewart 2011). Są one bowiem sposobami radzenia sobie z tym, co jeszcze nieznane, ale czego symptomy w pewien sposób doświadczane są w teraźniejszości. To zatem formy i sposoby negocjowania ,afektywnych stanów" (Vigh 2018) w życiu codziennym, które towarzyszą zarówno napięciom, konfliktom i kryzysom, jak również indywidualnym troskom, niepewnościom czy też nadziejom. Samo dostrajanie się ma więc charakter afektywny, dzięki czemu doświadczane na co dzień „coś” nabiera sensu i staje się „czymś” (Stewart 2007: 2). Mówiąc inaczej, dostrojenia to strategie racjonalizacji i społeczne praktyki nadawania znaczeń wyłaniającym się możliwym światom przyszłości, które często opierają się na indywidualnych nawykach, familiarnościach i rutynach życia codziennego, jak również humorze, ironii czy sarkazmie, dzięki którym możliwa przyszłość, przynajmniej na chwilę, oddala się od teraźniejszości (Stewart 2011: 445). Antycypowane wówczas obawy, niepewności i kryzysy schodzą na drugi plan, stają się jedynie tłem codzienności, od czasu do czasu 
Antycypacja, afektywne ekonomie i temporalność w (post)kryzysowej Islandii

przypominając jedynie o istniejących przyszłych możliwościach. Dostrojenia mogą być jednak także działaniem kolektywnym, którego celem jest aktywna zmiana scenariuszy przyszłości. Są one wówczas odpowiedzią na społeczne nastroje, jednoznaczną niezgodą na istniejącą strukturę ekonomiczną i polityczną świata, której potencjalnym rezultatem może być katastroficzna przyszłość. Dostrojenia wyrażane są zatem także w różnego rodzaju protestach, społecznych mobilizacjach i radykalnych żądaniach zmian, w których gniew często przeobraża się w nadzieję na to, że jednak możliwe są przyszłości inne niż zakładane w teraźniejszości.

W Islandii dostrajanie się ma różnorodną formę, częstotliwość i intensywność. Są to na przykład dyskursywne praktyki racjonalizowania i wyjaśniania wyobrażanej przyszłości, w ramach których antycypowany kryzys staje się zjawiskiem powtarzalnym i familiarnym, często przyrównywanym do erupcji gejzerów czy wulkanów. W konsekwencji reakcją na nadchodzący kryzys jest pewnego rodzaju obojętność, która zazwyczaj wyrażana jest za pośrednictwem idiomu kulturowego petta reddast (,wszystko dobrze się ułoży”). Samo już jednak czekanie na kryzys, także jest formą dostrajania, która pociąga za sobą praktyki spekulatywne. Jak bowiem zauważył Marcin podczas jednej z naszych rozmów:

Spotkałem się z kilkoma takimi zachowaniami, że ludzie jednak wstrzymują się z zakupem mieszkania, bo czekają na okazję i wiedzą, że jak będzie kryzys to mieszkania mogą być tańsze i lepsze. Bo wiesz, jak znowu walnie to wszystko, to ceny się zresetują. Mam w pracy dwóch kumpli, którzy tak robią i mieszkają u rodziców, i cały czas zbierają pieniądze. Wydaje mi się, że to jakby jest wycinek większego obrazu, że ludzie wstrzymują jakieś takie większe ruchy inwestycyjne.

Dostrajanie się może więc zakładać ekonomiczną kalkulację zysków i strategiczne myślenie o jutrze. Praktyki te nabrały szczególnego znaczenia po doświadczeniach kryzysu w 2008 roku, który schłodził przegrzaną wcześnie gospodarkę „szaleńczego milenium”. Według Marcina tego rodzaju spekulatywne czekanie może jednak mieć swe realne konsekwencje ekonomiczne:

Jest to samonapędzająca się machina i wystarczy takie po prostu poczucie kryzysu, żeby był kryzys. Bo to prowadzi do tego, że ludzie się inaczej zaczynają zachowywać. Wiesz, na zasadzie, że jeden ma przeczucie i drugi, i dołączają do siebie, i już coś spada albo się ochładza. I to wszystko tylko dlatego, że coś jest 
w powietrzu, co wcale nie musi być jakieś namacalne, bo to mogą być też plotki, które się rozbujają.

Nieco inaczej kwestie te postrzega pracujący w sektorze turystycznym Hallur, z którym spotykałem się, aby rozmawiać o islandzkiej historii, ekonomii i polityce. Dla niego bowiem, sam nastrój czekania i mówienia o kryzysie pokazuje raczej istniejącą dziś w Islandii czujność społeczną, dzięki której kolejny kryzys nie nastąpi i pozostanie jedynie w sferze spekulatywnych wyobrażeń:

Kryzys w 2008 roku był niespodziewany, nikt nie widział, że nadchodzi, nawet ludzie, którzy krytykowali wtedy działania banków tego nie przeczuwali. Wydawało się wszystkim, że przyszłość przyniesie bogactwo dla wszystkich. No i dlatego, że kryzys był niespodziewany, to teraz wszyscy antycypują, że będzie kolejny. No ale przyszłość jest trudna do przewidzenia i to, że kiedyś coś się stało nie oznacza przecież, że stanie się to ponownie. No ale wiesz, jak tylko w 2015 i 2016 zaczęło dziać się lepiej, wszyscy automatycznie zaczęli mówić o następnym kryzysie... Bo jak ludzie teraz widzą drogie samochody na ulicach to mają ten obraz z czasów tuż przed kryzysem. Ale to nie oznacza, że jest tu jakaś przyczynowość, wręcz przeciwnie - właśnie dlatego, że wszyscy antycypują kryzys to raczej oznacza, że on się nie zdarzy.

Dostrojenia są oczywiście zmienne, relacyjne i zależne od zmieniających się w teraźniejszości uwarunkowań społecznych, ekonomicznych i politycznych. Niemniej Hallur ma rację mówiąc, że nie ma żadnego realnego i przyczynowo skutkowego powiązania pomiędzy przeszłością i przyszłością. Z perspektywy antropologicznej istotne są tu jednak wskazane przez niego zależności, które dostrajają zmysły, praktyki i wyobrażenia w ramach antycypowania ,potencjalnych sposobów życia lub też przeżywanych rzeczy" (Stewart 2011: 452).

W konsekwencji antycypowanie przyszłości staje się współcześnie istotnym kontekstem produkowania wiedzy etnograficznej. Szczególnie, jeśli mowa o antycypowaniu, w którym temporalne skojarzenia ukazują różnego rodzaju sposoby myślenia o zależnościach, a sprawcze dostrojenia przekuwają je w racjonalizacje i praktykę społeczną. Eksploracja i problematyzacja takiego postrzegania przyszłości może stanowić interesujący i wartościowy poznawczo element zrozumienia naszego „bycia” w świecie: różnorodnych uwikłań społecznych, kulturowych, ekonomicznych i politycznych. 
Antycypacja, afektywne ekonomie i temporalność w (post)kryzysowej Islandii

\section{Podsumowanie}

W Islandii doświadczana codzienność wywołuje afektywną antycypację, w ramach której przeszłość i przyszłość stają się niemal równoczesne, oddziaływując przy tym wzajemnie na siebie. Przeszłość uaktualnia się w teraźniejszości i niemal natychmiast projektowana jest na najbliższą przyszłość. Z antropologicznego punktu widzenia nie jest oczywiście istotne to, czy doświadczane i temporalnie kojarzone w Islandii symptomy rzeczywiście zwiastują nadejście kolejnego kryzysu. Interesujący dla mnie badawczo jest raczej kontekst samego antycypowania kryzysu, jak i związanych z tym wyobrażeń i praktyk ukierunkowanych na możliwą, aczkolwiek nieznaną, przyszłość.

Antycypacja nie ogranicza się tylko i wyłącznie do Islandii. Wręcz przeciwnie, zdaje się ona być powszechnym aspektem współczesnego świata, w którym globalne siły i zależności mają znaczący wpływ na lokalne życie społeczne. Niemniej sama antycypacja rzadko bywa istotnym elementem przedsięwzięć etnograficznych. Jest to oczywiście związane $\mathrm{z}$ historią antropologii, w ramach której wytworzyła się specyficzna polityka temporalności zakładająca „logikę reprodukcji, siłę zwyczajów, dynamikę pamięci, trwanie habitusu, powolny ruch codzienności i podstępną tradycję w życiu społecznym" (Appadurai 2013: 285). Innymi słowy, to przeszłość - rozumiana jako „miniona” lub też „znikająca” - na długi czas „skolonizowała” antropologię, badane miejsca, sytuacje i aktorów społecznych" (Adams i in. 2009: 247). Przeszłość dominowała więc w opisach etnograficznych, konstruując jednocześnie „hermetyczne” i ,statyczne” przedstawienia „kultur”, które zazwyczaj pozbawione były dynamiki zmian, relacji i zależności. W konsekwencji przyszłość - poza nielicznymi wyjątkami (Gell 1992; Mead 2005; Munn 1992; Wallman 1992; por. Pink, Salazar 2017) - przez długi czas nie stanowiła znaczącego przedmiotu badań w antropologii i dopiero niedawno zaczęła być problematyzowana (Abram, Weszkalnys 2013; Appadurai 2013; Collins 2008; Hannerz 2016; Rosenberg, Harding 2005; Salazar, Pink, Irving, Sjöberg 2017).

Oczywiście, antropologia zawsze praktykowana jest w teraźniejszości (Rabinow i in. 2008), spoglądając na przeszłość i dialektykę ciągłości i zmiany, ale nie oznacza to, że powinna być ślepa na konteksty, w których to przyszłość nieustannie wyłania się jako wyobrażona. Spekulowanie, planowanie, projektowanie, prognozowanie są przecież silnie wpisane 
w teraźniejszość (tak jak i w przeszłość), wskazując jednocześnie na scenariusze możliwych przyszłości. Co więcej, istniejące zależności globalne i uwikłania społeczne, kulturowe, ekonomiczne i polityczne stanowią niezwykle ważne elementy doświadczania świata i jako takie mają znaczący wpływ na nastroje społeczne. Kryzysy ekonomiczne, polityczne, ekologiczne, w których biznes i polityka, kultura i natura są ze sobą sprzężone, wytwarzają antycypacyjne dyskursy i praktyki. Zakładana przyszłość może oczywiście nigdy się nie spełnić, jednak zawsze wprowadza kontekst afektywności - niepewności, niepokoju czy też nadziei - i domaga się reakcji (Adams i in. 2009: 249). Doświadczamy i odtwarzamy świat nie tylko w oparciu o to, „co było”, ale także o to „co będzie”, a zatem, aby wyjaśnić, jak „działa świat” musimy stworzyć „nowe powiązania pomiędzy indywidualną wyobraźnią a faktami społecznymi (Hastrup 2005: 8, 11, 16).

Antropologia, w której perspektywa etnograficzna i krytyczna refleksyjność uwrażliwia nas na ,palące kwestie” współczesności, ma ogromny potencjał wyjścia poza klasycznie rozumianą temporalność. Uwaga badawcza skierowana na antycypację i możliwe przyszłości może więc pokazać i sproblematyzować istniejące zależności pomiędzy doświadczeniami, sposobami rozumienia i praktykami w kontekście wyobrażanych przyszłości (zob. Narotzky, Bresnier 2014: 13). Tego rodzaju antropologiczne dociekania nie zatrzymują się na przeszłości, a raczej nieustannie poruszają się pomiędzy przeszłością i przyszłością, rzucając jednocześnie poznawcze światło na teraźniejszą dynamikę procesów, praktyk, relacji i zjawisk. Nie chodzi więc o to, że stajemy się prorokami przepowiadającymi przyszłość na podstawie obserwowanych codzienności. Naszym celem badawczym nie jest poznanie tego, „co” się stanie, ale raczej wyjaśnienie, w jaki sposób, kiedy i dlaczego ludzie antycypują, że „coś” się stanie.

\section{BIBLIOGRAFIA}

Abu-Lughod, L. (1991). Writing Against Culture, W: R.G. Fox (red.) Recapturing Anthropology: Working in the Present (s. 467-478). Santa Fe: A School of American Research Press.

Abram, S., Weszkalnys, G. (2013). Elusive Promises: Planning in the Contemporary World. Oxford-New York: Berghahn Books. 
Antycypacja, afektywne ekonomie i temporalność w (post)kryzysowej Islandii

Adams, V., Murphy, M., Clarke, A.E. (2009). Anticipation: Technoscience, life, affect, temporality. Subjectivity, 28, 246-265.

Ahmed, S. (2004). Affective economies. Social Text, 22(2), 117-139.

Alibar, R.Z., Zoega, G. (red.) (2011). Preludes to the Icelandic Financial Crisis. Basingstoke New York: Palgrave Macmillan.

Appadurai, A. (2013). Future as Cultural Fact: Essays on the Global Condition. London: Verso.

Bergmann, E. (2014). Iceland and the International Financial Crisis. Boom, Bust and Recovery. Basingstoke-New York: Palgrave Macmillan.

Bernburg, J.G. (2015). Overthrowing the Government: A Case Study in Protest, W: E.P. Durrenberger, G. Pálsson (red.) Gambling Debt. Iceland's Rise and Fall in Global Economy (s. 63-77). Boulder: University of Colorado Press. Boyes, R. (2010). Meltdown Iceland. London-Berlin-New York: Bloomsbury. Brubaker, R., Cooper, F. (2000). Beyond "identity". Theory and Society, 29, 1-47. Collins, S.G. (2008). All Tomorrow's Cultures: Anthropological Engagements with the Future. Oxford-New York: Berghahn Books.

Connor, L.H., Marshall, J.P. (red.) (2015). Environmental Change and the World's Futures: Ecologies, Ontologies and Mythologies. New York: Routledge.

Durrenberger, P.E., Pálsson, G. (red.) (1989). The Anthropology of Iceland. Iowa City: University of Iowa Press.

Durrenberger, P.E., Pálsson, G. (red.) (2015) Gambling Debt. Iceland's Rise and Fall in Global Economy. Boulder: University of Colorado Press.

Fortun, K. (2012). Ethnography in Late Industrialism. Cultural Anthropology, 27(3), 446-464.

Gell, A. (1992). The Anthropology of Time - Cultural Constructions and Temporal Maps and Images, Oxford: Berg.

Guðjónsdóttir, G., Loftsdóttir, K. (2016). Being a desirable migrant: perception and racialisation of Icelandic migrants in Norway. Journal of Ethnic and Migration Studies, 43(5), 791-808.

Hannerz, U. (2016). Writing Future Worlds. An Anthropologist Explores Global Scenarios. London: Palgrave MacMillan.

Hastrup, K. (1998). A Place Apart. An Anthropological Study of the Icelandic World. Oxford: Clarendon.

Hastrup, K. (2005). Performing the World: Agency, Anticipation and Creativity, The Cambridge Journal of Anthropology, 25(2), 5-19.

Hastrup, K. (2013). Anticipating Nature: The Productive Uncertainty of Climate Models, W: K. Hastrup and M. Skrydstrup (red.), The Social Life of Climate Change Models. Anticipating Nature (s. 1-29). New York-London: Routledge. 
Hastrup, K., Skrydstrup, M. (red.) (2013). The Social Life of Climate Change Models. Anticipating Nature. London and New York: Routledge.

Hirsch, E., Stewart, C. (2005). Introduction: Ethnographies of Historicity. History and Anthropology, 16(3), 261-274.

Holmes, D.R., Marcus, G.E. (2006). Fast Capitalism: Para-Ethnography and the Rise of the Symbolic Analyst, W: M.S. Fisher, G. Downey (red.), Frontiers of Capital. Ethnographic Reflections on the New Economy (s. 33-57). Durham: Duke University Press.

Illouz, E. (2010). Uczucia w dobie kapitalizmu (przeł. Z. Simbierowicz). Warszawa: Oficyna Naukowa.

Jóhannesson, G.Th. (2015). Exploiting Icelandic History: 2000-2008, W: E.P. Durrenberger, G. Pálsson (red.), Gambling Debt. Iceland's Rise and Fall in Global Economy (s. 15-22). Boulder: University of Colorado Press. Kazubowski-Houston, M. (2018) An Elephant in the Room: Tracking an Awkward Anthropology. Anthropologica, 60, 413-426.

Kleist, N., Jansen, S. (2016). Introduction: Hope over Time-Crisis, Immobility and Future-Making. History and Anthropology. DOI:10.1080/02757206.20 16.1207636

Knight, D.M., Stewart, C. (2016). Ethnographies of Austerity: Temporality, Crisis and Affect in Southern Europe. History and Anthropology, 27(1), 1-18.

Loftsdóttir, K. (2010), The Loss of Innocence: The Icelandic Financial Crisis and Colonial Past. Anthropology Today, 26(6), 9-13.

Loftsdóttir, K. (2012). Colonialism at the margins: politics of difference in Europe as seen through two Icelandic crises. Identities: Global Studies in Culture and Power, 19(5), 597-615.

Loftsdóttir, K. (2015). Vikings Invade Present-Day Iceland, W: E.P. Durrenberger, G. Pálsson (red.) Gambling Debt. Iceland's Rise and Fall in Global Economy (s. 3-14). Boulder: University of Colorado Press.

Loftsdóttir, K. (2016). The Danes don't get this': the economic crash and Icelandic postcolonial engagements. National Identities, 18(1), 35-51.

Loftsdóttir, K. (2018). Finding a place in the world. Political subjectivities and the imagination of Iceland after the economic crash. Focaal-Journal of Global and Historical Anthropology, 80, 63-76.

Lutz, C. (2017). What matters. Cultural Anthropology, 32(2), 181-191.

Marcus, G.E. (1986). Contemporary Problems of Ethnography in the Modern World System, W: J. Clifford, G.E. Marcus (red.), Writing Culture. Politics and Poetics of Ethnography (s. 165-193). Berkley: University of California Press. 
Antycypacja, afektywne ekonomie i temporalność w (post)kryzysowej Islandii

Marcus, G.E. (1995). Ethnography in/of the World System: The Emergence of Multi-Sited Ethnography. Annual Review of Anthropology, 24, 95-117.

Mead, M. (2005). The World Ahead: An Anthropologist Anticipates the Future. New York: Berghahn Books.

Mixa, M.W. (2009). Once in Khaki Suits: Socioeconomical Features of the Icelandic Collapse, W: I. Hannibalsson (red.), Rannsóknir i Félagsvísindum X (s. 435-447). Reykjavík: Háskólaútgáfan.

Mixa, M.W. (2015). Day in the Life of an Icelandic Banker, W: E.P. Durrenberger, G. Pálsson (red.) Gambling Debt. Iceland's Rise and Fall in Global Economy (s. 33-46). Boulder: University of Colorado Press.

Munn, N. (1992). The cultural anthropology of time: A critical essay. Annual Review of Anthropology, 21, 93-123.

Narotzky, S., Besnier, N. (2014) Crisis, Value, and Hope: Rethinking the Economy. Current Anthropology, 55, 4-16.

Ong, A., Collier, S.J. (red.) (2005). Global assemblages. Technology, politics, and ethics as anthropological problems. Malden: Blackwell Publishing.

Pawlak, M., (2018) Zawstydzona tożsamość. Emocje, ideologie i władza w życiu polskich migrantów w Norwegii. Kraków: Wydawnictwo Uniwersytetu Jagiellońskiego.

Pálsson, G. (1993). From Commons to Quotas: The Formation of Icelandic Fisheries Policy. North Atlantic Studies, 3(2), 17-24.

Pálsson, G. (1996). Commodity Fiction and Cod Fishing. Nordic Journal of Political Economy, 23(1), 75-86.

Pálsson, G., Durrenberger, E.P. (red.) (1996). Images of Contemporary Iceland: Everyday Lives and Global Contexts. Iowa City: University of Iowa Press.

Pálsson, G. Durrenberger, E.P., (2015). Introduction: The Banality of Financial Evil, W: E.P. Durrenberger, G. Pálsson (red.), Gambling Debt. Iceland's Rise and Fall in Global Economy (s. XIII-XXIX). Boulder: University of Colorado Press.

Pink, S., Salazar, J.F. (2017). Anthropologies and futures. Setting the agenda, W: J.F.

Salazar, S. Pink, A. Irving and J. Sjöberg (red.) Anthropologies and Futures. Researching Emerging and Uncertain Worlds (s. 3-22). Bloomsbury: London-New York.

Rabinow, P., Marcus, G.E., Faubion, J. D., Rees, T. (2008). Designs for an anthropology of the contemporary. Durham: Duke University Press.

Richard, A., Rudnyckyj, D. (2009). Economies of affect. Journal of the Royal Anthropological Institute, 15, 57-77. 
Rosaldo, M. (1984). Toward an anthropology of self and feeling, W: R.A. Shweder, R.A. LeVine (red.), Culture Theory: essays on mind, self, and emotion (s. 137-157). Cambridge: Cambridge University Press.

Rosenberg, D., Harding, S. (red.) (2005). Histories of the Future. Durham-London: Duke University Press.

Salazar, J.F. (2017). Speculative fabulation: Researching worlds to come in Antarctica, W: J.F. Salazar, S. Pink, A. Irving and J. Sjöberg (red.) Anthropologies and Futures. Researching Emerging and Uncertain Worlds (s. 151-170). Bloomsbury: London-New York.

Salazar, J.F., Pink, S., Irving, A., Sjöberg, J. (red.) (2017). Anthropologies and Futures. Researching Emerging and Uncertain Worlds. Bloomsbury: London-New York.

Skaptadóttir, U.D. (2015). What Happened to the Migrant Workers? W: E.P. Durrenberger, G. Pálsson (red.) Gambling Debt. Iceland's Rise and Fall in Global Economy (s. 175-185). Boulder: University of Colorado Press. Skoggard, I., Waterston, A. (2015). Introduction: Toward an Anthropology of Affect and Evocative Ethnography. Anthropology of Consciousness, 2(26), 109-120.

Stewart, K. (2007). Ordinary Affects. Durham-London: Duke University Press.

Stewart, K. (2011). Atmospheric attunements. Environment and Planning D: Society and Space, 29, 445-453.

Wallman, S. (red.) (1992). Contemporary Futures: Perspectives from Social Anthropology. London-New York: Routledge.

Wojtyńska, A., Skaptadóttir, U.D., Ólafs, H. (2011). The Participation of Immigrants in Civil Society and Labour Market in the Economic Recession. Reykjavík: Faculty of Social and Human Sciences, University of Iceland.

Vigh, H. (2018). Lives opposed: perceptivity and tacticality in conflict and crime. Social Anthropology, 26(4), 487-501. 